\begin{tabular}{|c|l|}
\hline Title & $\begin{array}{l}\text { Possible involvement of an impaired baroreflex mechanism but not the renin-angiotensin system } \\
\text { and vasopressin in the enhanced pressor responsiveness to physostigmine in spontaneously } \\
\text { hypertensive rats }\end{array}$ \\
\hline Sub Title & \multicolumn{1}{|l|}{} \\
\hline Author & $\begin{array}{l}\text { 川島, 紘一郎(Kawashima, Koichiro) } \\
\text { 三輪, 裕子(Miwa, Yuko) } \\
\text { 藤本, 和子(Fujimoto, Kazuko) }\end{array}$ \\
\hline Publisher & 共立薬科大学 \\
\hline Publication year & 1987 \\
\hline Jtitle & $\begin{array}{l}\text { 共立薬科大学研究年報 (The annual report of the Kyoritsu College of } \\
\text { Pharmacy). No.32 (1987.),p.69-69 }\end{array}$ \\
\hline JaLC DOI & \\
\hline Abstract & \\
\hline Notes & 抄録 \\
\hline Genre & Technical Report \\
\hline URL & $\begin{array}{l}\text { https://koara.lib.keio.ac.jp/xoonips/modules/xoonips/detail.php?koara_id=AN00062898-0000003 } \\
\text { 2-0069 }\end{array}$ \\
\hline
\end{tabular}

慶應義塾大学学術情報リポジトリ(KOARA)に掲載されているコンテンツの著作権は、それぞれの著作者、学会または出版社/発行者に帰属し、その権利は著作権法によって 保護されています。引用にあたっては、著作権法を遵守してご利用ください。

The copyrights of content available on the KeiO Associated Repository of Academic resources (KOARA) belong to the respective authors, academic societies, or publishers/issuers, and these rights are protected by the Japanese Copyright Act. When quoting the content, please follow the Japanese copyright act. 
No. 32 (1987)

\title{
Possible Involvement of an Impaired Baroreflex Mechanism but not the Renin-Angiotensin System and Vasopressin in the Enhanced Pressor Responsiveness to Physostigmine in Spontane- ously Hypertensive Rats
}

\author{
Koichiro Kawashima, Yuko Miwa and Kazuko Fujimoto \\ 川島紘一郎, 三輪裕子, 藤本和子
}

1. Effects of physostigmine on heart rate, mean arterial pressure (MAP), plasma renin concentration (PRC) and vasopressin (AVP) release were investigated in spontaneously hypertensive (SHR) and Wistar-Kyoto (WKY) rats.

2. Physostigmine $(100 \mu \mathrm{g} / \mathrm{kg}$, i.a.) produced a greater and prolonged hypertensive response in the SHR than in the WKY.

3. Heart rate was increased by physostigmine in SHR rats while it was unchanged in the WKY.

4. PRC was unchanged or even slightly decreased in these animals when MAP was increased by physostigmine.

5. An AVP pressor antagonist did not attenuate the pressor and cardiac effects of physostigmine in these animals.

6. These data indicate that an impaired baroreflex mechanism or a different mode of sympathetic neuronal activation by physostigmine through the central mechanism appears to be contributory, at least in part, to the enhanced pressor responsiveness in the SHR.

7. The renin-angiotensin system and AVP do not appear to be involved in the enhanced pressor responsiveness to physostigmine in SHR rats.

本報告は Gen. Pharmacol., 18, 327-330（1987）に発表. 